\title{
Sceptics and salmon challenge scientists
}

[SEATTLE] A sharp controversy has broken out around the scientific uncertainties involved in proposals to introduce a new, ecosystembased approach to save dwindling salmon stocks found in the Columbia River basin, the main river system in the northwestern United States.

Plans to restore the stocks could include dynamiting four hydroelectric dams on the Snake River, the Columbia's largest tributary (see map), the annual meeting of the American Association for the Advancement of Science (AAAS) was told in Seattle last week.

But any such solution will face a mountain of opposition, not just from power and agricultural interests, but from a public that has grown deeply sceptical over the years as billions of dollars have been thrown at salmon conservation efforts in the river system, with little impact. The scepticism extends to the science behind it.

"Science has been part of our planning process for decades," says Ted Strong of the Columbia River Inter-tribal Fish Commission, a native American advocacy group. "It is attempting to take a lead role again, but it can't atone for the destruction it has already caused."

An annual salmon run of 16 million fish on the river system during the early part of this century has declined to around one million, according to the US National Marine Fisheries Service, with only ten per cent of these being spawned naturally. The rest are spawned in man-made hatcheries along the river system.

\section{Dam destruction and genes}

Overfishing of the stocks in the middle of the century is thought to have precipitated a decline which was compounded by the construction of extensive hydroelectric systems along the Columbia and Snake rivers. Hatcheries were supposed to compensate for the disruption caused by the dams. But some scientists think that they have actually contributed to the decline by weakening the gene pool of naturally born salmon.

Poor scientific understanding of the cause of the decline may undermine support for radical solutions, the AAAS meeting was told. According to John Etchart, a senior official with the Northwest Power Planning Council-abody set up by Washington, Oregon, Idaho and Montana to manage the river basin - the council is legally mandated to apply the best science.

But Etchart characterizes scientific knowledge of the issue as "unsettled and uncertain", adding that the fate of the proposal to breach the four dams on the Snake River "will turn on how certain we are of its benefits".

An independent scientific advisory group, chaired by Richard Williams, a population

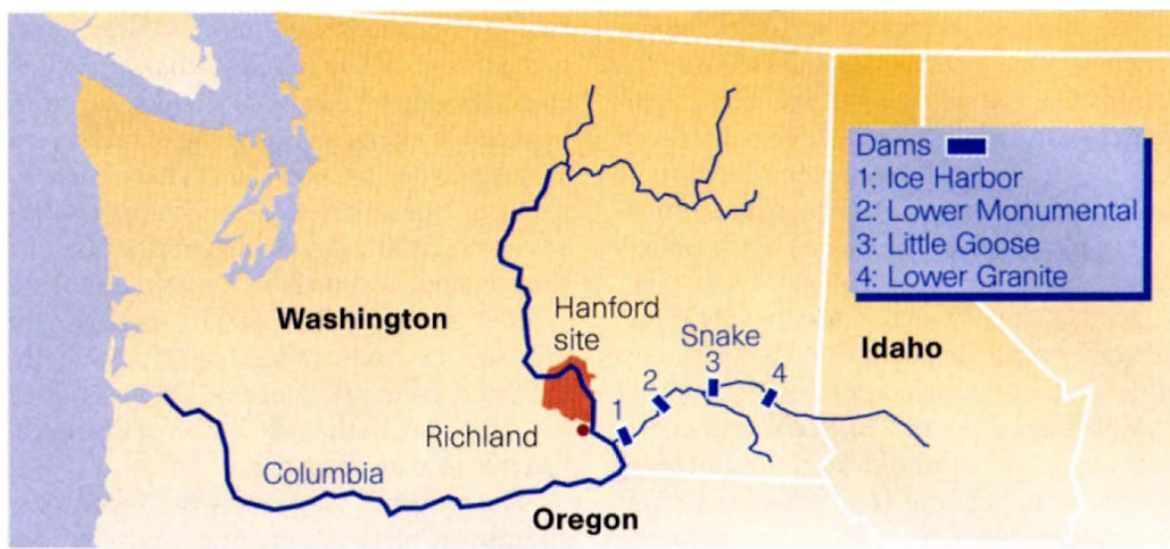

geneticist at the University of Idaho, has been established to advise the council. Last year, the group's brief was widened to advise the fisheries service, the main federal agency working on the issue, and the National Research Council in Washington helped to strengthen its membership and procedures.

The group's draft report, Return to the river, was recently published for public comment. It includes the dam-busting plan. Williams stresses that the report is not an action plan for the Columbia River basin, but rather a "conceptual foundation, based on established ecological principles", on which such a plan could be based.

The report argues that management of the Columbia system should aim to restore to the heavily managed river characteristics typical of a large, natural salmon river. In contrast with previous plans, which concentrated on local action to conserve specific species, it tackles the whole river, acknowledges its complexity as a system, and "recognizes the failures of the past", says Williams.

A plan to save the ecosystem, he says, should seek to preserve those stretches still operative - such as the Hanford Reach of the Columbia itself, the only free-flowing section of the river south of the Canadian border, which still yields 150,000 or 200,000 salmon a year - and to restore other parts of the river, then to reconnect these stretches.

But the good faith of these scientific advisers is questioned by Strong, whose talk was originally entitled "Is there too much science in the Columbia River Basin?", until organizers toned it down to the more restrained "Science in the Tribal Restoration Plan". Strong accuses scientists involved of arrogance towards nature, adding: "It isn't science that is offered: it is science that does not interfere with money-making on the Columbia."

Williams counters that tribal advocates want it both ways: they claim, with some justification, that the scientists have at last come round to their way of thinking, but they still argue that science can't be trusted to come up with ways to fix the problem. He worries that tribal advocates are more interested in continuing arguments than in embracing solutions.

These solutions are increasingly assumed to lie in destroying some of the dams. "We have turned a once-raging river into a series of reservoirs," says Donna Darm of the fisheries service. Salmon prosper on the Hanford Reach, where the Columbia is free-flowing, and only four dams - each with fish ladders - separate the spawning grounds from the Pacific Ocean, where the fish spend much of their adult lives before returning upstream to spawn.

But the additional four dams on the Snake River seem to be too much for the salmon to negotiate, Williams says. The decline in the overall salmon harvest in the Columbia basin was almost complete before these four dams were constructed but, Williams believes, the removal of the dams would restore natural salmon spawning on the Snake River and its tributaries in Idaho and western Montana.

\section{Science and public perception}

Darm says that their demolition would cost $\$ 1$ billion, plus around $\$ 250$ million a year in lost hydroelectric power. At present, around $\$ 450$ million is spent each year on programmes to restore fisheries in the Columbia basin - although half of this goes on subsidies for the hydropower.

Attempts to restore the stocks could also be dogged by false public perceptions of what has gone wrong. According to Courtland Smith, a sociologist at Oregon State University, surveys have shown that the public considers "water quality" to be the main reason the salmon have gone, with overfishing by foreign fishermen in the Pacific Ocean the next biggest problem. Neither factor is viewed as significant by scientists or fishery managers.

"We've spent \$2-3 billion on salmon recovery to date, and the results have been disappointing," says Etchart. "Science is not to blame, but it has played a part. There are serious questions about whether what we spend now [on fisheries management and research] is cost-effective." 